\title{
Influence of Tillage Depth and Plough Speed on Performance of Primary Tillage Tools
}

\author{
Jagseer Singh $^{1}$, Sukhpal Singh Chatha ${ }^{2}$ and Buta Singh Sidhu ${ }^{3}$ \\ ${ }^{1 \& 2}$ Yadavindra College of Engineering, Punjabi University Guru Kashi Campus, Talwandi Sabo, Punjab, India \\ ${ }^{3}$ Maharaja Ranjit Singh Punjab Techanical University, Bathinda, Punjab, India \\ E-Mail: er.jagseersingh@yahoo.com
}

\begin{abstract}
In India near about $60 \%$ population is engaged in agriculture. Soil loosening is a primary method of cultivation before seeding. There are number of tillage tools used for primary cultivation i.e. cultivators, rotary tillers, moldboard plough and chisel plough, rotavators etc. During soil cultivation wear occurs due to interaction of tillage implement and soil particles, which in turn decreases tillage quality and increase draft forces and fuel consumption of tractor. Tool wear reduces farmer's efficiency, costing millions of dollars per year to Nation's economy. Knowledge of tillage depth and ploughing speed save the tillage time and improves tractor efficiency. In this study it is attempted to relate the influence of tillage depth and tractor speed on primary tillage tools.

Keywords: Soil Loosening, Tillage Tools, Draft Forces, Chisel Plough, Tillage Depth
\end{abstract}

\section{INTRODUCTION}

In India agriculture is the single largest sector, acts as a growth engine by ensuring food and nutritional security to the masses besides providing raw-materials to agro-based industries and also providing employment and thereby income to the rural folk of the State and Indian Economy. India had a large and diverse agricultural sector, accounting, on average, for about $15 \%$ of GDP and $11 \%$ of export earnings (U.S. Dept. of Agri., 2014). Preparation of land with tillage tools provides more reliable and enables the farmers to achieve his target at right time. Various tillage tools are used for primary cultivation. The main objective of primary tillage by different methods is to loosen the soil, weed control and to bury corps residue (Hakansson et al., 1998).

During cultivation tillage tool rubs by soil particles, causes wear of implements. The wear rate on tillage tools is mostly affected by soil-tool pressure distribution. It becomes more serious as energy costs get higher because farm machinery contributes the major portion of the overall cost of crop production (Askari et al., 2017). Tillage depth and tractor speed are most important operational parameters that influence the draught forces. Khushwaha and Linke (1996) reported that draught requirements of tillage implements as a function of operating speed is a significant criterion for evaluating tillage tools by field or laboratory. The enhancement of the operational efficiency of tractors has been a subject of considerable research. Chancellor and Thai (1984), Grogan et al., (1987) and Smith (1993) states that up to $20 \%$ potential savings could be achieved by gearup throttle-down method.

Another technique to enhance the operational efficiency is exact selection of tractor and tillage implement. Furthermore, Michel et al., (1985) reported that proper selection of an efficient tool, such as chisel ploughshare rather than mouldboard plough, can cut down the tillage energy requirements up to $40 \%$. Studies on influence of tractor speed and tillage depth were conducted by many researchers (ASAE., 1993; Khushwaha and Linke., 1996; Summers et al., 1986). Furthermore, Al-Jonabi and AlSuhaibani (1998) developed the general equation for primary tillage tools (Mouldboard plough, three chisel ploughs of different shanks, disc plough and an offset disc harrow). The researchers reported that tractor speed and tillage depth had significant linear effect on draught of all tillage tools. It is observed that due to increase in speed or tillage depth, draught forces increases linearly. The increase in draught forces reduces the tractor efficiency and increases more fuel penalties, which affect National economy badly.

\section{FACTORS AFFECTING THE PERFORMANCE OF PRIMARY TILLAGE TOOLS}

\section{A. Effect of Tractor Forward Speed on Draught Requirement}

Tractor forward speed is most prominent operational parameter that influences the draught forces, which directly affects the tillage quality and tractor fuel consumption. Draught requirements were changed due to increase or decrease with forward speed and type of implement used same order of magnitude has been found by Molari et al., (2017). The researchers found that with increase in speed at an optimum level $(4.2 \mathrm{Km} / \mathrm{h})$ the soil pressure increases linearly, after that decrease with increase in speed.

Furthermore, Taniguchi et al., (1999) observed the effect of forward speed and optimal plow attachments on draft forces and soil manipulation. This research was conducted in summer 1997 and forward speeds ranging from 1.0 to 4.0 $\mathrm{m} / \mathrm{s}$ with an interval of $0.5 \mathrm{~m} / \mathrm{s}$. Fig. 1 shows the speed-force relationship of moldboard plough. The linear relationship were observed in Fig.1, same results were found by other 
researches (Al-Jonabi \& Al-Suhaibani.,1998; Molari et al., 2017; Al-suhaibani et al., 2006; Aykas et al., 2004; Stafford., 1979; Simens et al., 1965). Author reported that this kind of speed-draft relationship results mainly from the forces required to accelerate the soil blocks and to prevail over the shear resistance.

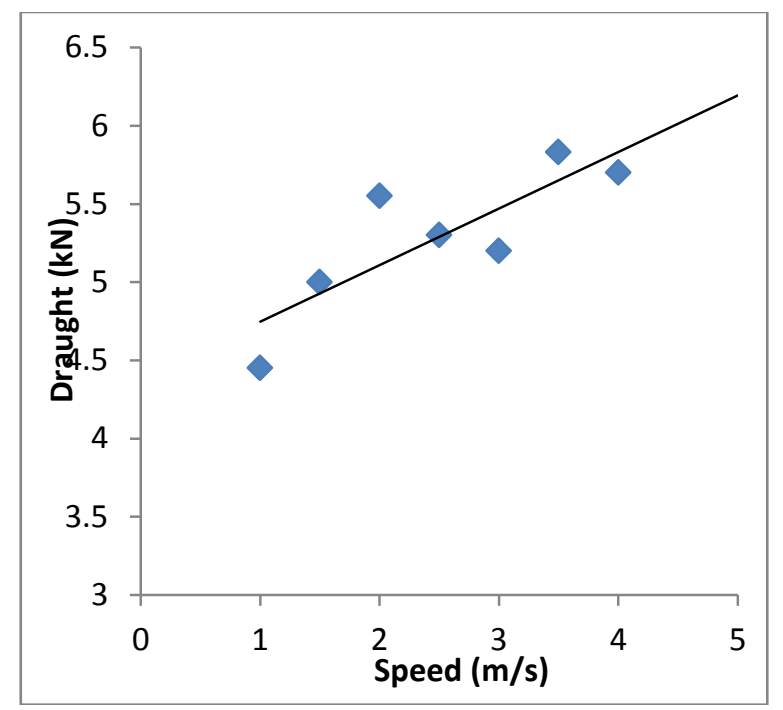

Fig. 1 Relationship between travel speed and draft force (Taniguchi et al., 1999)

Al-Suhaibani \& Al-Jonabi.,(1997) examined the effect of tillage speed and depth on draught of chisel plough, moldboard plough, disc harrow and an offset disc harrow at two different sites. From Figures 2-4 shows the variation of draught forces acting on different implements at depth of 100,150 and $200 \mathrm{~mm}$. It is observed that for the same depth and range of speed, draught force acting on moldboard and disk ploughs were higher than the chisel plough and offset disk harrow. This could be due to the change in shape and size of the implement. The remarkable increase in draught was reported for all the implements due to change in speed and depth of tillage tools.

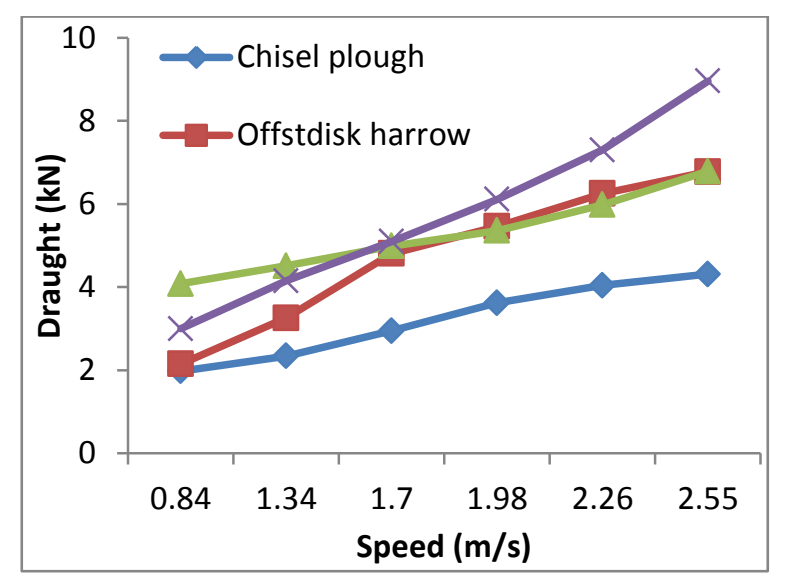

Fig. 2 Variation of specific draught of the four implements at depth of 100 mm (Al-Suhaibani \& Al-Jonabi.,1997)

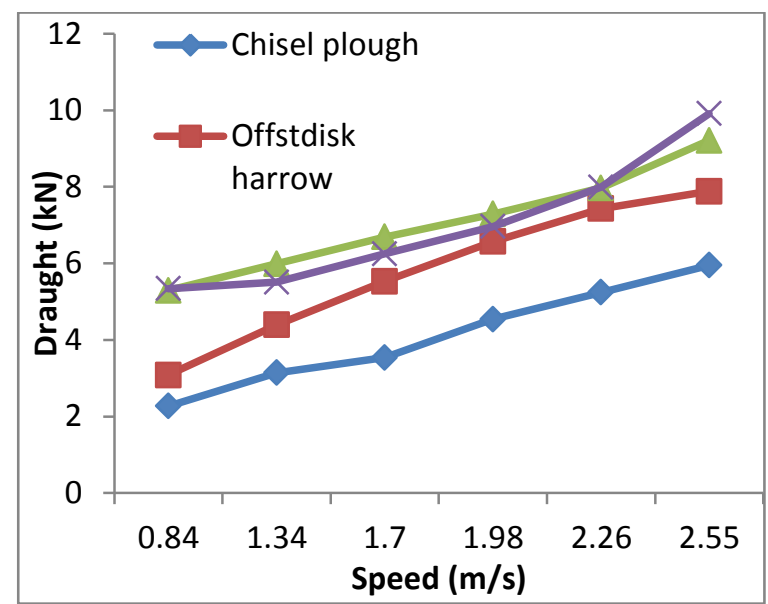

Fig. 3 Variation of specific draught of the four implements at depth of $150 \mathrm{~mm}$ (Al-Suhaibani \& Al-Jonabi.,1997)

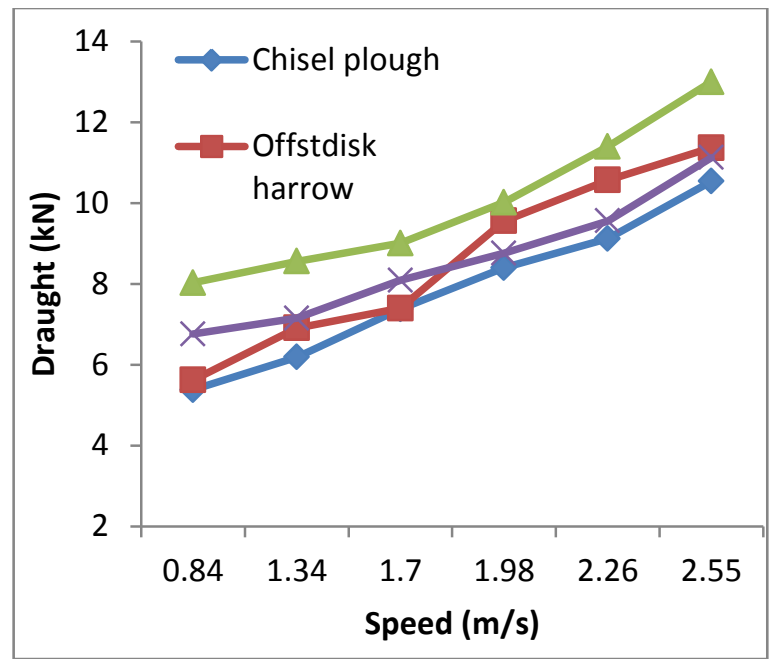

Fig. 4 Variation of specific draught of the four implements at depth of $200 \mathrm{~mm}$ (Al-Suhaibani \& Al-Jonabi.,1997)

\section{B. Effect of Tillage Tool Depth on Draught Requirement}

Another factor influencing the performance of primary tillage tools is ploughing depth of implements, which affects the energy requirements, tillage time and cost. Arvidsosn et al., (2004) studied the effect of moisture content on specific draft forces of chisel plough, moldboard plough and disc harrow. The author found that with decrease in moisture content, the cohesion strength of different soils increases simultaneously and vice-versa. So, here it is observed that moisture content in soil also affects the draught forces. Hakansson et al., (1998) studied the optimal ploughing depth of moldboard plough under various conditions in Sweden. Author used 19 sites in Sweden with ploughing depth about 15, 22 and $28 \mathrm{~cm}$. It is concluded that for sandy soils, relatively deep tillage upto $30 \mathrm{~cm}$ is required for physical reasons. Shallow ploughing should be chosen for soils with high content of fine slit. Again for clay soil and clay loam soil deep ploughing is preferred, but due to higher energy requirements and high cost of ploughing, it is not recommended more than $22-25 \mathrm{~cm}$. 
Raper (2002) conducted the study on implement type and tillage depth. In this research author conducted study in fall and spring season on disk plough and chisel plough with depth of 7.6 and $15.2 \mathrm{~cm}$. Fig. 5 shows that draught force was considerably higher in spring and fall seasons for deep chisel plough, more than twice than disk plough in every season. Linear characteristics were observed between draught force and tillage depth for chisel and disk plough. The minimum draught force was required by disk-shallow treatment. Draught force increases with increase in tillage depth.

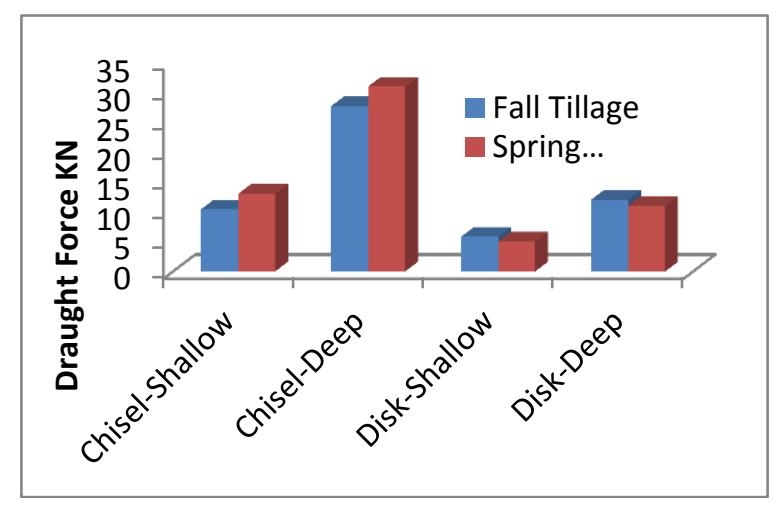

Fig. 5 Relationship between draught force and tillage depth (Raper 2002)

Similar results were also found by others (Owen 1989; Collins \& Fowler 1996). Grisso et al., (1996) observed the effect of speed and tillage depth on operating forces on different tillage implements in silty clay loam soil. The effect of tillage depth on draught of chisel plough, tandem disk and field cultivators were found to have more influence than travel speed.

The effect of tillage depth $(50,100$ and $150 \mathrm{~mm})$ and tillage speed $(0.57$ and $1.4 \mathrm{~m} / \mathrm{s})$ on soil cutting forces was studied on different implements by Rahman \& Chen., (2001). For all tillage implements and tillage speeds, tillage depth is more critical than speed of tillage tool, in terms of influence of draft forces. Draft force behaves linear with working depth. At the same tillage depth, sweep tool requires more draft forces than the disc type tool. Godwin et al., (2007) studied the mathematical model for prediction of draught forces on moldboard plough incorporating the effect of soil properties and ploughing speed. From Figures 6 and 7 it is observed that the linear relationship shows between depthforce and speed-force same results were found by other researches (Kalantari et al., 2014; Naderloo et al., 2009; Sahu \& Rehman, 2006; Manuwa, 2009). However, the increase in draught forces is much greater for increase in depth than for increase in speed over typical practical ranges.

\section{Effect of Tillage Speed, Depth and Draught Forces on Fuel Consumption}

Efficiency of tractor (Fuel consumption) is more important in tillage system. There are many types of primary tillage tools used for soil loosening, requires energy according to the type of tillage tool. According to Natsis et al., (1999) in sandy soils wear of tillage tools increases with increase in moisture content and inversely proportional for loam and clay soils. This increase in wear leads to increase in draught forces of moldboard plough. Author found that with increase in tool edge thickness from 1 to $6 \mathrm{~mm}$, draught forces increased by $62 \%$ and fuel consumption increased by $41 \%$ and rate of work decreased by $30 \%$.

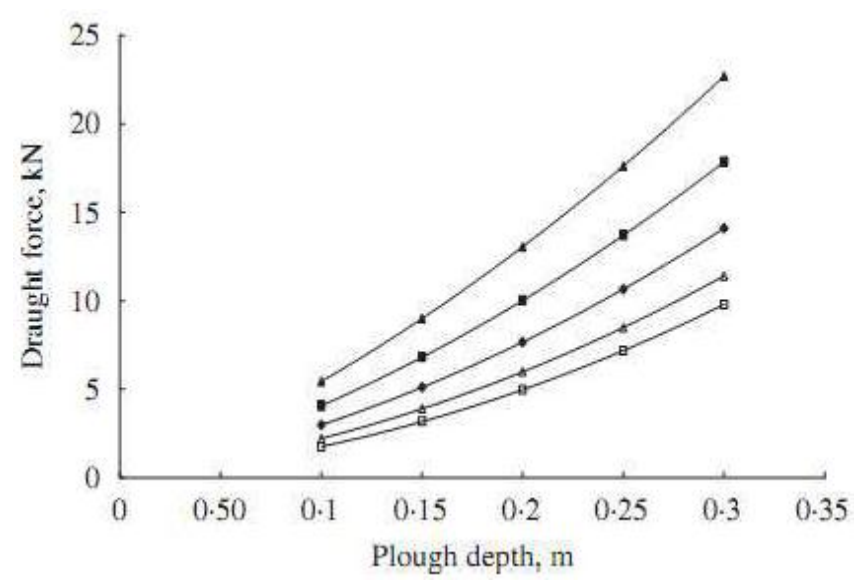

Fig. 6 Effect of depth on predicted draught force for plough for a range of forward speeds $\square 1 \mathrm{~m} / \mathrm{s} ; \Delta 2 \mathrm{~m} / \mathrm{s} ; 3 \mathrm{~m} / \mathrm{s} ; 4 \mathrm{~m} / \mathrm{s} ; \Delta 5 \mathrm{~m} / \mathrm{s}$ forward speed (Godwin et al., 2007)

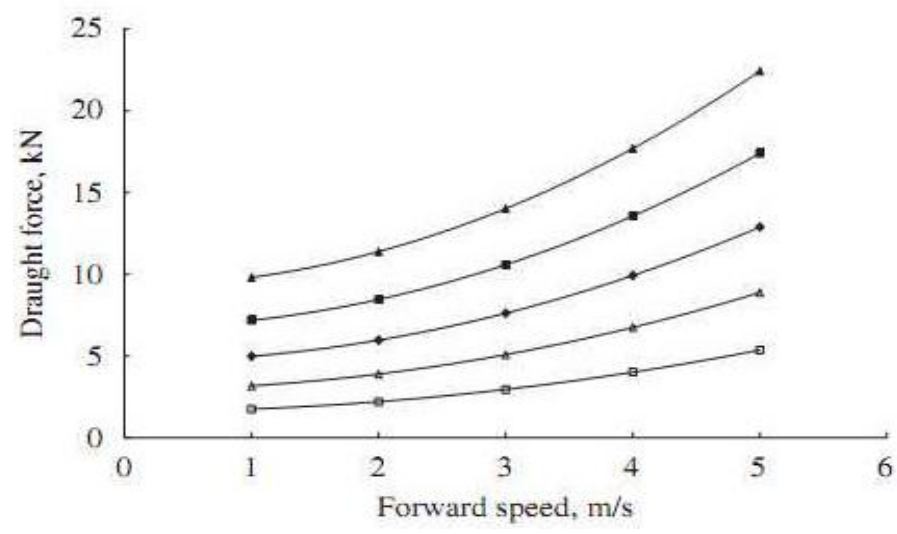

Fig. 7 Effect of tillage speed on predicted draught force for plough for a range of depths $\square 0.1 \mathrm{~m} ; \Delta 0.15 \mathrm{~m} ; 0.2 \mathrm{~m} ; 0.25 \mathrm{~m} ; \boldsymbol{\Delta} 3 \mathrm{~m}$ tillage depth (Godwin et al., 2007)

Askari et al., (2017) measured the performance of tractor and tillage implements. Three tillage tools i.e. moldboard plough, disk plough and chisel plough were examined at different forward speeds $(1.5,2.3,3$ and $4 \mathrm{~km} / \mathrm{h})$ at $23 \mathrm{~cm}$ tillage depth. They found that increase of forward speed results increase in draught forces, causes increase in fuel consumption. Similar results of increase in fuel consumption have also been reported by Kichler et al., (2011) and Kheiralla et al., (2004). These increase in draught forces influence the energy requirements. Fig. 8 shows the influence of speed and implements type on fuel consumption. 


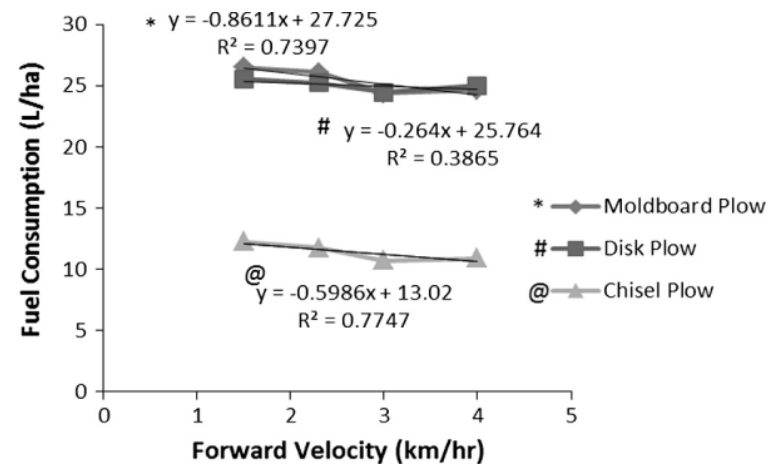

Fig. 8 Relationship between tractor speed, fuel consumption and implement type (Askari et al., 2017)

It is observed from Fig. 8, with increase in tractor forward speed from 1.5 to $3 \mathrm{Km} / \mathrm{h}$, fuel consumption of the tractor decreased. Fuel consumption of tractor further increases with speed increase in speed from 3 to $4 \mathrm{Km} / \mathrm{h}$. Higher fuel consumption was measured for moldboard plough and lowest for chisel plough. Moitzi et al., (2013) studied the influence of working width of moldboard plough $(3,5$ and 7 tines) at depth of $25 \mathrm{~cm}$ and $\mathrm{T}$-trailed cultivator with working depth of 15 and $25 \mathrm{~cm}$. Fig. 9 shows that performance of tractor increases with the working width of ploughs. Area ploughed by three tine $(2 * 3)$ moldboard plough is $0.5 \mathrm{ha} / \mathrm{h}, 1.9 \mathrm{ha} / \mathrm{h}$ for five tine $(2 * 5)$ and $2.3 \mathrm{ha} / \mathrm{h}$ for seven tine $(2 * 7)$. For cultivators at depth of $25 \mathrm{~cm}$ is $2.58 \mathrm{ha} / \mathrm{h}$ and at depth of $15 \mathrm{~cm}$ is $3.7 \mathrm{ha} / \mathrm{h}$.

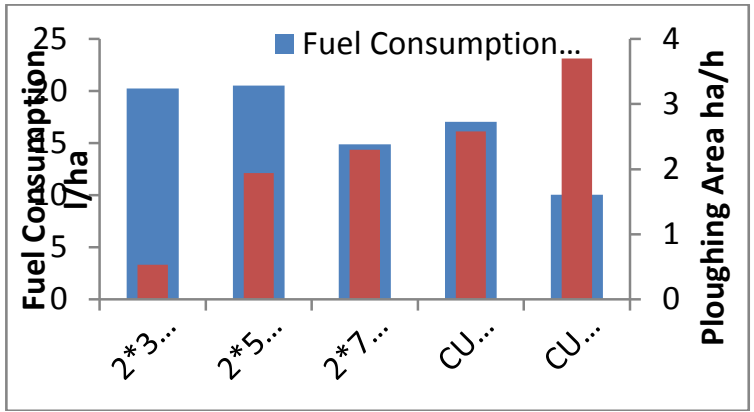

Fig. 9 Shows relationship between plough width, depth, plough type, ploughing area and fuel consumption

Here, from Fig. 9 it is also noticed that with decrease in cultivator depth from 25 to $15 \mathrm{~cm}$, performance of tractor increased. With increase in working depth of the cultivators, the fuel consumption of tractor increases by $70 \%$. Furthermore, effect of tillage depth on tractor fuel consumption was studied by Fathollahzadeh et al., (2010). A moldboard plough was used in this study at $0.15,0.25$ and 0.35 meter depth. In Fig. 10, results showed that tractor with moldboard plough consumes fuel 27.44, 30.09 and $34.061 /$ ha for the depth of $0.15,0.25$ and $0.35 \mathrm{~m}$ respectively. Fuel consumption of tractor increased $9.66 \%$ and $24.10 \%$ when depth of plough increased 0.15 to $0.25 \mathrm{~m}$ and 0.15 to $0.35 \mathrm{~m}$ respectively. For working depth 0.20 to $0.25 \mathrm{~m}$ average fuel consumption $30 \mathrm{l} / \mathrm{ha}$ was measured.

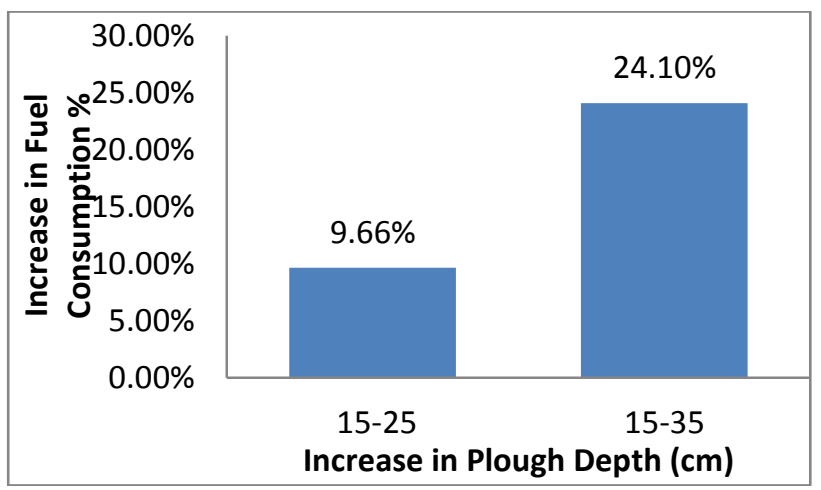

Fig. 10 Influence of working depth on fuel consumption

\section{CONCLUSION}

1. With increase in tillage depth and speed of tractor, the draught force increases. However, the tillage depth has more significant impact the draught forces as compare to the tractor speed.

2. Tractor speed and working depth of implements influences the draught forces, which in terms influences the fuel consumption.

3. Width of tillage tool is also an important factor which affects the draught forces and fuel consumption, but overall efficiency increased with the increase in width of tillage tool.

\section{REFERENCES}

[1] India's Agricultural Exports Climb to Record High, United States Department of Agriculture, 2014.

[2] I.Hakansson, M.Stenberg and T. Rydberg, "Long-term experiments with different depths of mouldboard ploughing in Sweden", Soil Till. Res. Vol. 46, pp. 209-223, 1998.

[3] S.Ranjbarian, M.Askari and J.Jannatkhah, "Performance of tractor and tillage implements in clay soil", Journal of the Saudi Society of Agricultural Sciences, Vol. 16, pp. 154-162, 2017.

[4] R.L. Kushwaha, and C. Linke, "Draft-speed relationship of simple tillage tool at high operating speeds", Soil Till. Res, Vol. 39: 61-73, 1996.

[5] W.J. Chancellor, N.C.Thai, "Automatic control of tractor transmission ratio and engine speed", Trans. ASAE, Vol. 27, No. 3, pp. 642-646, 1984.

[6] J.D.Grogan, A. Moris, S.W. Searcy, B.A. Stout, Microcomputer based tractor performance monitoring and optimization system. $J$. Agric. Eng. Res., Vol. 38, 227-243, 187.

[7] L.A Smith, "Energy requirements for selected crop production implements", Soil Till. Res., Vol. 25, No. 4, pp. 281-299, 1993.

[8] Michel Jr., J.A., Fornstrom, K.J., Borelli, J., "Energy requirements of the tillage systems for irrigated sugarbeets, dry beans and corn",Trans. ASAE, Vol. 28, No. 6, pp. 1731-1735, 1985.

[9] ASAE. ASAE S313.2: "Agricultural machinery management data". ASAE Standards, pp. 657-658, ASAE, St Joseph, MI 49085-9659, 1993.

[10] Summers, J.D., Khalilian, A., Batchelder, D.G.'Draft relationships for primary tillage in Oklahoma soils", Trans. of the ASAE, Vol. 29, No. 1, pp. 37-39, 1986.

[11] A.A. Al-Janobi, and A.A. Al-Suhaibani, "Draft of primary tillage implements in sandy loam soil",Trans. of the ASAE, Vol. 14, No. 4, pp. 343-348, 1998.

[12] M.Mattetti, M.Varani, G. Molari and F.Morelli "Influence of the speed on soil-pressure over a plough", Biosystems Engineering, Vol. 156, 136-147, 2017.

[13] T.Taniguchi, J.T.Makanga, K. Ohtoma and T. Kishimoto, "Draft and soil manipulation by a moldboard plow under different forward speed 
and body attachments", Transactions of the ASAE, Vol. 42, pp. 15171521.

[14] S.A. Al-Suhaibani, A.A Al-Janobi, Y.N. Al-Majhadi, Tractors and tillage implements performance. Written for presentation at the CSBE/SCGAB 2006 Annual Conference Edmonton Alberta July 1619, 2006

[15] E.Aykas, E. Cakir and E. Gulsoylu , "The effect of tillage parameters on the performance of heavy duty offset disk harrow" "Asian Journal of Plant Sciences", Vol. 3(4, pp. 425-428, 2004

[16] J.V. Stafford "The Performance of a Rigid Tine in Relation to Soil Properties and Speed", J. agric. Engng Vol. 24, pp. 41-56, 1979

[17] J.C .Siemens, J. A.Weber, and T. H. Thornburn "Mechanics of Soil as Influenced by Model Tillage Tools"Transactions of the ASAE, pp. 17, 1965.

[18] S.A. Al-Suhaibani, and A. Al-Janobi, "Draught requirements of tillage implements operating on sandy loam soil",Journal of Agricultural Engineering Research, Vol. 66, No. 3, pp. 177-182, 1997.

[19] J.Arvidsson, T. Keller and K. Gustafsson "Specific draught for mouldboard plough, chisel plough and disc harrow at different water contents",Soil \& Tillage Research, Vol. 79, 221-231, 2004.

[20] R. L. Raper "The influence of implement type, tillage depth and tillage timing on residue burial Transactions of the ASAE", Vol. 45, No.5, pp.1281-1286, 2002.

[21] G. T. Owen "Force-Depth Relationships in a Pedogenetically Compacted Clay Loam Soil", Applied Engineering In Agriculture, Vol.5, No.2 pp.185-191, 1989.

[22] B.A. Collins and D. B. Fowler "Effect of soil characteristics, seeding depth, operating speed, and opener design on draft force during direct seeding” Soil \& Tillage Research Vol. 39, pp.199-211, 1996.

[23] R D Grisso, M .Yasin, "M F Kocher Tillage tool forces operating in silty clay loam", Transactions of the ASAE, Vol. 39, pp.1977-1982, 1996.

[24] S.Rahman, and Y. Chen "Laboratory investigation of cutting forces and soil disturbance resulting from different manure incorporation tools in a loamy sand soil",Soil and Tillage Research, Vol. 58,No.1, pp. 19-29 2001.

[25] R.J. Godwin, M.J. O’Dogherty, C. Saunders and A.T. Balafoutis , “A force prediction model for mouldboard ploughs incorporating the effects of soil characteristic properties, plough geometric factors and ploughing speed" Biosystem Engineering Vol.97, pp.117 - 129, 2007.

[26] A. Moeenifar, S.R Mousavi-Seyedi. and D. Kalantari “ Influence of tillage depth, penetration angle and forward speed on the soil/thin-blade interaction force". Agric Eng Int: CIGR Journal Vol.16, No. 1,pp 69-74, 2014.

[27] L.Naderloo, R. Alimadani, A. Akram, P. Javadikia, and H. Z. Khanghah. "Tillage depth and forward speed effects on draft of three primary tillage implements in clay loam soil", Journal of Food, Agriculture and Environment, Vol. 76,No.3,pp 382-385, 2009.

[28] R.K.Sahu, H.Raheman, 2006. "Draught prediction of agricultural implements using reference tillage tools in sandy clay loam soil", Biosyst. Eng Vol 942, 275-284,2006.

[29] S.I. Manuwa "Performance evaluation of tillage tines operating under different depths in a sandy clay loam soil. Soil \& Tillage Research", Vol. 103, pp 399-405, 2009.

[30] A.Natsis, G. Papadakis and J. Pitsilis, "The Influence of Soil Type, Soil Water and Share Sharpness of a Mouldboard Plough on Energy Consumption, Rate of Work and Tillage Quality", Journal of Agriculture Engineering and Research Vol. 72, pp 171-176,1999.

[31] C.M. Kichler, J.P Fulton, R.L.Raper, "McDonald, T.P., Zech, W.C., 2011. Effects of transmission gear selection on tractor and fuel costs during deep tillage operation", Soil \& Tillage Research Vol. 113, pp. 105-111.

[32] A F Kheiralla , A Yahya, M. Zohadie, W Ishak "Modelling of power and energy requirements for tillage implements operating in Serdang sandy clay loam", Malaysia. Soil and Tillage Research, Vol. 78, pp. 21-34, 2004.

[33] G .Moitzi, M. Haas, H.Wagentristl, J. Boxberger and A. Gronauer. "Energy consumption in cultivating and ploughing with traction improvement system and consideration of the rear furrow wheel-load in ploughing”, Soil \& Tillage Research. Vol. 134, pp. 56-60, 2013

[34] H .Fahollahzadeh, H. Mobli, A. Rajabipour, S. Minaee, A. Jafari, and S.M.H Tabatabaie, "Average and instantaneous fuel consumption of Iranian conventional tractor with moldboard plow in tillage", ARPN Journal of Engineering and Applied Sciences, Vol. 5, No.2, pp. 30$35,2010$. 